\title{
Ageing in the Urban Context: Evidence from Sarajevo'
}

\author{
Mirza Emirhafizović, Sanela Šadić
}

\begin{abstract}
The permanent increase in the proportion of persons aged 65 and over in Bosnia and Herzegovina $(\mathrm{BiH})$ is hardly recognized as an issue that deserves due public attention. Compared to those cities striving for standards of age-friendly urban environment proposed by World Health Organization (WHO), social conditions for active ageing in BiH capital Sarajevo are evidently suboptimal. Since ageing is at the same time an individual process, the main purpose of the paper is to examine satisfaction with the quality of life among senior citizens through a survey. The research was carried out on a sample of 103 older persons who are users of four existing centres for healthy ageing in the city. In addition to the semi-structured questionnaire, semi-structured interviews with senior citizens and coordinators at centres for healthy ageing were also conducted. Senior citizens - most of them a generation of Baby-boomers - were asked questions regarding income, loneliness, family relationships, social participation, leisure, life satisfaction, physical environment as well as mobility. In doing so, some topic areas of age-friendliness, such as social participation, outdoor spaces and public transportation in Sarajevo have been evaluated. Contrary to assumptions, respondents are quite content with their social life. Nevertheless, apart from enhancing of older people's social inclusion in general, various structural changes are necessary in order to convert Sarajevo into a more age-friendly city. The establishment of centres for healthy ageing is certainly a step forward in that direction.
\end{abstract}

KEY WORDS age-friendly city; active ageing; quality of life; Sarajevo

\section{Introduction}

"(A) house or an apartment becomes a prison if the older person cannot get the services, friends, and recreation." (Bernardin-Haldemann 1982, as cited in Novak 1993: 301)

Age-friendly orientation could be observed in the light of an increased social sensitivity towards addressing the older population's specific and diverse needs that were, to a greater or lesser degree, neglected in the past. Altered societal circumstances, coupled with the dominant demographic trends (population ageing) have favoured the raising public

Sociální studia / Social Studies 1/2018. Pp. 85-98. ISSN 1214-813X.

1 The authors would like to express their great appreciation to users and coordinators at centres for healthy ageing in Sarajevo for their willingness to participate in the research. They are very grateful to the anonymous reviewers whose comments helped improve the quality of the paper. Their special thanks are extended to the journal editors - Lucie Vidovićová and Pavel Pospěch - for their support and constructive suggestions, which shaped this manuscript. 
awareness of how important it is to create all the necessary conditions for active ageing (Buffel and Phillipson 2016). This is closely linked to reducing many forms of old-age social exclusion across the various domains entailing multifaceted approach (Walsh, Scharf and Keating 2016). Enhancing the quality of life of older adults is the pivotal objective of the age-friendly city concept developed by the World Health Organization (WHO 2007), which highlights the promotion of their social inclusion in a broad sense. Following these introductory remarks, the paper is intended to shed a light on the social reality in the context of active ageing. With the exception of the occasional media reporting, population ageing is not perceived by the government as an alarming issue in spite of its progressive character. Consequently, the increase in the proportion of the population aged 65 and over, both in Bosna and Herzegovina and its capital Sarajevo, is not accompanied by adequate policy response $^{2}$. Many contextual factors contribute to the age-inclusive discourse being pushed in background, thus deprioritizing the convergence towards many aspects of age-friendly community. Hence, active ageing is poorly researched, which corresponds to the lack of interest for this age group.

An inspection into the particular circumstances may enable better comprehension of social attitude towards older people, so it is advisable to briefly present the situation in the post-socialist period. Unlike the other European cities, Sarajevo experienced the nearly four-years siege in 1990s which had deeply affected its urban development. In the aftermath, the normalization of life, which included the rebuilding of the severely destroyed city had been among the top priorities since 1996 onwards. The post-conflict and transitional society is burdened with numerous problems producing the permanent crisis: war legacy, transition to market economy, structural unemployment, corruption, outflow of youth abroad, depopulation, political tensions etc. Older adults are undeniably one of the most socially vulnerable groups, with a high percentage of them living in poverty due to low income. Additionally, the lack of institutional support to older people could be largely attributed to the traditionally pronounced familism, although the structure of the family and relationships within it have changed over the last few decades.

Taking into account all the presented facts, the paper raises the question on the satisfaction of older people with the quality of life in Sarajevo from their own perspective. Empirical foundation that resulted from the surveying of senior citizens might be an incentive for raising public awareness about the importance of an appropriate policy response. However, the establishment of centres for healthy ageing represent a positive example of providing services for older persons with the support of local communities.

2 Bosnia and Herzegovina, a signatory state to the Madrid International Plan of Action on Aging (2002) and the revised European Social Charter (2008), has agreed to develop policies, strategies and action plans that will enable healthy and active aging of its population as well as develop a system that will enable regular data collection and international reporting on the successes associated with active aging of the population (Strategija 2017: 3). 


\section{Demographic profile of Sarajevo}

The City of Sarajevo ${ }^{3}$ - the capital of Bosnia and Herzegovina - is comprised of four urban municipalities (Stari Grad Sarajevo, Centar Sarajevo, Novo Sarajevo and Novi Grad Sarajevo), and has 275,524 inhabitants (according to the 2013 Census data ${ }^{4}$ ). The most densely populated municipality is Novo Sarajevo, followed by Novi Grad which has the highest number of residents.

World population is ageing, and Bosnia and Herzegovina as well as Sarajevo are no exception to this global trend (UN 2015). Basically, as an outcome of a persistent reduction in birth rates and an increase in life span, younger cohorts are being outnumbered by the older ones, which leads not only to the permanent transformation of sex/age structure, but also to the disturbance of established relationships in society. In addition to natural change, both internal and external migration also play an important role in reshaping the population pyramid. Its status as the capital of Bosnia and Herzegovina makes Sarajevo one of the country's most attractive cities for internal migrants (UNDP 2013).

A comparison of the 1991 Census (conducted in the eve of the war) and the 2013 Census data points out a significant deterioration in the age structure of all observed municipalities. This is particularly pronounced to its extremes as the ratio of the young population (0-19 years old) has fallen, while the 65-and-older age group's proportion has grown. The great portion of Baby-boomers (generation born after the Second World War up to the mid-60s) has already reached the retirement age. Comparative perspectives allow a better understanding of why the old-age contingent acquires substantially different social traits as the Baby-boomers are ageing (Phillipson 2007).

In the three city municipalities (Stari Grad, Centar and Novo Sarajevo), the number of children under 15 has dropped more than twice over the interim period, which lasted for 22 years. Demographic processes were strongly affected by the war (1992-1995), generating long-term consequences. Many residents left Sarajevo during and after the siege while the internally displaced persons came to the city, mostly from Eastern Bosnia, due to forced expulsion. Therefore, urban, semi-urban or rural background of city residents can be correlated with different ageing patterns among them in terms of social engagement, degree of dependency, health behavior, etc., so this fact should be borne in mind when discussing the issue.

The largest increase in the number of persons aged 60 and over took place in the municipality with the youngest population, and that is Novi Grad. The least vital local community is Centre with the equal proportions of persons under the age of 20 and those aged 65 and over, recording at the same time a negative natural change since 2000 . Novi Grad is the only city

3 In this paper, the City of Sarajevo is used in the context of territorial scope only and not in the sense of its competences as a unit of local self-government. Municipalities comprising the City of Sarajevo with the two neighbouring, Ilidža and Vogošća, form a compact urban area. The Sarajevo Canton consists of 9 municipalities (those belonging to the City of Sarajevo plus five more) altogether forming a functional urban area. Peripheral municipalities (Ilijaš, Hadžići and Trnovo) of the Canton are more rural than urban.

4 Available at www.fzs.ba. 
municipality which still yields a natural increase, albeit with declining tendency in recent years. The average age of Sarajevo residents is approximately 41, and is somewhat higher than the national average.

Figure 1: Proportions of major age groups in total population of city municipalities

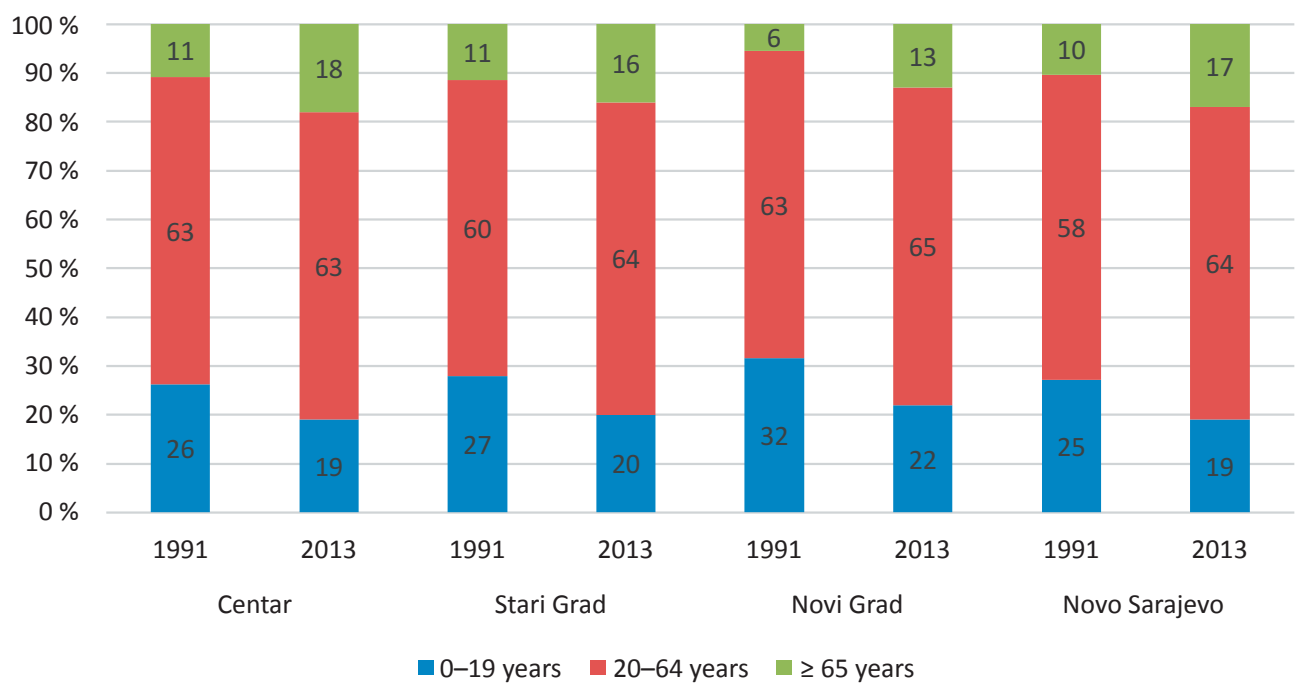

Source: Institute for Statistics of FBiH, the 1991 Census results; the 2013 Census results (available at: www.fzs.ba)

Due to gender differences in life expectancy, women prevail in the third age, and especially among the oldest-old. This worldwide phenomenon is known as feminization of ageing. It should be emphasized that, in all four municipalities, a relatively high percentage of persons belonging to the age group 60-80 and over fits into one of the following categories: never been married, divorced or widow/widower, ranging from $44 \%$ (Novi Grad) over $45 \%$ (Centar and Novo Sarajevo) to $47 \%$ (Stari Grad). These data suggest the likelihood of living by themselves or in institutions. Continually low birth rates and an increased life span will inevitably result in population ageing even at a progressive pace.

\section{Methodological notes}

The quality of life of the older people and the concept of active aging should increasingly so become a part of socio-political measures and general attitude toward this category. The purpose of this research is to evaluate the satisfaction of older persons with the most important segments of the quality of life in the City of Sarajevo with beneficiaries of Healthy Ageing Centres. The underlying questions of the research are: how do senior citizens in urban environment assess their quality of life and how satisfied are they with life; how do they spend their time; how they assess family relationships, how they assess social participation, 
what opportunities exist for a quality time; how do they evaluate the services of public transport and mobility conditions in the City of Sarajevo.

Social inclusion is founded on several important principles, with socioeconomic circumstances being only one of the preconditions. In order to improve the quality of life of the older persons and their greater involvement in the life of the community, the concept of healthy aging is being accepted and is finding its place in the City of Sarajevo. The first Healthy Aging Centre was established in the Novo Sarajevo Municipality in 2009, with the support of an international nongovernmental organization. Local authorities have recognized the importance of such day care centres for the improvement of health and quality of living of older people and have fully assumed the obligation to finance these centres.

The research was conducted in the area of the City of Sarajevo where four existing Healthy Aging Centres (Centri za zdravo starenje) are active: Centre for Healthy Aging Stari Grad, Centre for Healthy Aging Novo Sarajevo, Centre for Healthy Aging Centar and Centre for Healthy Aging Velešici. A total of 1,250 people use the services of these centres. The study included 103 older persons ( 84 females and 18 males), in the age range from 60 to 85 , with an average of 72 years of age. The proportion of females in the sample is $82 \%$, which is proportional to the gender structure of the total number of users in the Healthy Aging Centres. The survey method, along with semi-structured interviews were used for data collection.

For the purposes of this research, a semi-structured questionnaire was prepared, containing 21 questions. The questionnaire is structured in several parts (socio-demographic data, quality of life and life satisfaction, family relationships, leisure, transportation and mobility). In addition to the survey questionnaire, ten retirees were interviewed, questions were mainly concerned with public transport services and the level of satisfaction with life in the city. In addition, an interview with the coordinator of the older persons volunteer program was conducted.

The data obtained through the questionnaire were analyzed with SPSS, and the most important answers were summarized and analyzed through descriptive statistics.

\section{Discussion of research findings}

Income and quality of life

Low pensions and exposure to poverty, health problems and lack of services have a significant impact on the quality of life of older people. Poor societies are constantly preoccupied with meeting their basic existential needs, while "upward" needs, such as high-quality leisure time remain ignored by majority. The heterogeneous demographic structure of people over 65 years requires sensitization of society in terms of developing services that will address the needs of this diverse group of older persons. It is recognized that poor health conditions and low standard of living are the basic predictors of a sub-standard quality of life. The most vulnerable older persons are those who are suffering from chronic diseases, have the lowest income, and do not have family members who can take care of them or help them, neither financially nor otherwise. At the same time, this does not mean that the concept of active, 
healthy aging should be reserved only for wealthy and healthy individuals. The society must develop adequate mechanisms that will result in the provision of a whole spectrum of services designed to improve the quality of life of older people. In this regard, productive and enjoyable leisure time must also be considered.

Retirement is not only a psychologically difficult period; it is also an uneasy situation due to the heightened awareness of a very hard financial situation which will be almost impossible to overcome without the financial support of children. Social inequality is equally present among the older persons in different parts of the country ${ }^{5}$. A large number of pensioners who are not covered by pension insurance receive occasional or permanent social assistance, while the others do not have any income beside family support. The poorest in urban area are the beneficiaries of soup kitchens. It is also noteworthy that the majority of older persons have health problems, meaning that they spend most of their money on medications.

This research reveals that service users of Healthy Ageing Centres have a slightly better income compared to the rest of the older people. According to data obtained from this research, $51.1 \%$ of the respondents receive a monthly income ranging from 400-699 BAM (approximately 200-350 EUR), an amount that exceeds the average pension in the country. The reason for slightly more favourable socio-economic conditions of day care centres service users can be related to several important facts. The majority of respondents are domicile population ( $84 \%$ ), highly educated $(41.7 \%$ with university diploma and $50.5 \%$ with secondary school level of education), thus they had better paid jobs and consequently have higher pensions. At the same time, $37.9 \%$ of respondents have children living abroad and financially helping their parents. A smaller number of respondents, $21.3 \%$ have the lowest income, absolutely insufficient for a dignified living. Intergenerational solidarity here comes to play as an extremely important factor for the survival of the society as a whole. An important feature of the Bosnian society is that family ties are still cherished, and mutual support has always been an important moral and human value. For this reason, the proportion of those who think that they have enough income to ensure a dignified living is not negligible $(40.6 \%)$. Nevertheless, the majority $(59.4 \%)$ still live in poverty which is largely reflected in the quality of life and limited opportunities for leisure time activities.

\section{Leisure time activities}

The quality of life and active ageing are influenced by several factors including health, financial possibilities, place of living, communication network and public transport, as well as marital and family status, education, social and cultural origin. The City of Sarajevo has a rich cultural heritage and offers many opportunities for a rich and eventful life, very often reserved for older persons with better socio-economic opportunities and developed cultural habits. Since it is also a traditional society, the majority of older persons spend time in the family circle. According to the earlier survey, conducted in 2006 on a sample

5 In the Federation of Bosnia and Herzegovina, for example, the range of pensions is from 326 BAM (lowest) to 2,174 BAM (highest), while the situation in Republika Srpska is even worse with a range of 171 BAM (lowest) and 1,794 BAM (highest). 
of 400 senior individuals in the City of Sarajevo, the majority of them (75.3\%) do not attend any cultural activities (theatre, cinema, exhibitions, literary evenings, etc.) The situation is slightly better when it comes to sports "activities", since some of them (17.5\%) occasionally go to sports matches, hiking, walking in the nature, playing social games, and so on. It is devastating that $85 \%$ of respondents do not have any recreational activities, and only few occasionally go to local community offices reserved for senior citizens, where they socialize and enjoy the company of their peers (AKTIVA 2007).

Since centres for healthy ageing offer a variety of possibilities and content for service users; in comparison to the rest of their generation, they tend to become much more active. According to the results of our research, on the question: How do you spend free time? we obtained the following results: $35.9 \%$ spend time with their family; $16.5 \%$ with relatives; $56.3 \%$ with friends; $17.5 \%$ with neighbors; $9.7 \%$ babysitting the grandchildren; $5.8 \%$ are engaged in agriculture; $62.1 \%$ participate in different social events (gatherings, excursions, celebrations, religious rituals); $13.6 \%$, generally spend time alone although they go to day care centres from time to time; $40.8 \%$ are occupied with hobbies like painting, hiking, chess, sewing, reading, and walking. The majority of respondents $(74.8 \%)$ think there are enough opportunities in the City of Sarajevo to spend a quality leisure time. Furthermore, older people in the Bosnian society, especially women, play an important role in child care of the grandchildren. The modest income of young parents with small children, in combination with low income of older people, simply "dictate" this trend of intergenerational solidarity. Interestingly, the formerly popular "grandmother babysitting service" has been replaced by some other forms of childcare, as data shows that less than ten percent of the respondents are providing child care of their grandchildren.

\section{Loneliness and family relationships}

One of the most serious problems for older people is loneliness. According to the previous research of Caritas on older persons (2010), almost half (48.5\%) of the respondents report feelings of loneliness (Caritas 2010). Similarly, Kepeš (2012) finds that $19.7 \%$ of older persons have no friends, and $25.1 \%$ have one friend, while the majority $(41.1 \%)$ spend their time in the family circle and actively contribute to households (house work, garden maintenance, domestic animals breeding, grandchildren babysitting). Loneliness is one of the most important problems as pointed out by $44 \%$ of the older people in the European Union (Walker 1993, as cited in Vuletić and Stapić 2013). Vuletić and Stupić (2013) pointed out that the feeling of loneliness is linked to the density of social networks. Therefore, those with dense social networks are more active and more satisfied with their lives.

Loneliness is very much related to the marital status, place of living as well as social network (children, grandchildren, relatives and friends). Service users of the Healthy Ageing Centres are at a lower risk of loneliness since their social network is denser. The majority of respondents in this research are widowed (48\%), while $30.4 \%$ of them are married, divorced or live alone. Marital status is a significant characteristic in this phase of life, which significantly determines the quality of life, and the loss of a spouse is one of the traumatic experiences in this age, which has the greatest effect on the sense of loneliness. Most 
respondents have children (88.2\%), with the average of two children, while $11.8 \%$ are childless. Significant percentage of respondents have children living abroad (31\%) or outside Sarajevo (3.9\%), which considerably contributes to the social isolation due to the loss of important life roles.

It is significant that the majority of respondents have their own children still living in Sarajevo (48.5\%) who are regularly visiting them (44.7\%). A smaller percentage of respondents $(10.2 \%)$ pointed out that their children rarely visit them. On the issues related to the frequency of their children's visits, the majority of respondents $(42.7 \%)$ consider this question a very personal and intimate one, therefore they refrained from giving any response. The importance of this segment in life of older people cannot be ignored, especially due to the fact that the Bosnian society is still traditionally oriented, with parents expecting regular visits as well as help and support from their children.

Figure 2: Life satisfaction (in \%)

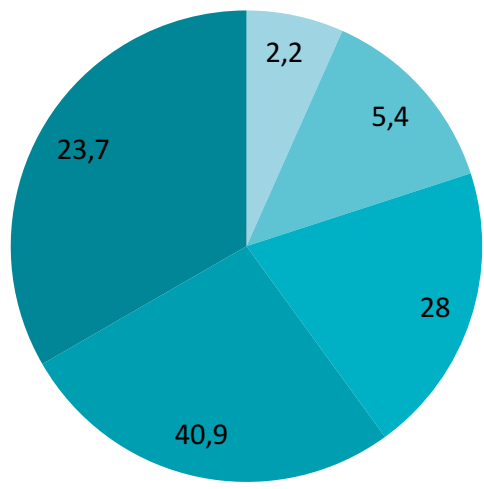

\author{
Extremely dissatisfied \\ Dissatisfied \\ Neither satisfied nor \\ dissatisfied \\ - Satisfied \\ Extremely satisfied
}

Source: own research

Generally speaking, older persons are not dissatisfied with life; the average grade of satisfaction with life on a scale from 1 to 5 is at 3.42. The surveyed population has solid assumptions for better grades and greater satisfaction with life, since they are spending more quality time in Healthy Aging Centres, they are more satisfied with the socioeconomic status, and majority have children who help them. These are important assumptions that can be positively correlated with a greater feeling of satisfaction of the service users in day care centres.

\title{
Volunteering
}

As a model of social participation, volunteering is not so popular in the Bosnian society. Activism among the older persons is none more popular as compared to activism in other categories, for example, a large proportion of younger people think activism is a waste of time with no benefit to them. In a survey conducted in 2006 (AKTIVA 2007), the largest number of older persons possess knowledge and skills in social, technical, cultural and healthcare 
type of activities, as well as house work. On the other hand, most of them think that they do not possess the skills and knowledge they could share with others. The reason could be an increasing apathy and lack of interest which has become a dominant characteristic of the social climate in the post-war period. Countries that invest in human development are more likely to have a higher percentage of older people volunteering and partaking a more active role in local communities (HelpAge International 2015).

Extremely concerning is the fact that the highest percentage of retirees belong to the category with the lowest pensions which are entirely insufficient to meet the basic needs. This can be an important part of the explanation for the lack of motivation regarding volunteering and activism. At the same time, possible poor health conditions among senior population can be important limiting factors for such engagement. In order to improve the attitude of older persons towards activism ${ }^{6}$ and voluntarism, at least among those who are willing and able, some kind of material or moral satisfaction should be considered.

During the exploration of the phenomenon of activism in older population, we found that there is an existing project in Sarajevo focused on mobilization of peer solidarity. There are obvious examples of horizontal solidarity, where healthy older people provide help for the sick and the impoverished. The most vulnerable category are older and sick people without family members and relatives who can take full care of them. The main role of the volunteers is to bring hope to their sick and lonely peers by reading them a book or newspapers, playing social games or simply talking to them. In urban areas, there is a growing number of older people who do not have family members who would take care of them, including those without children and with children who live abroad. Peer solidarity is a significant support mechanism, primarily resting on the power of empathy as the key driving force.

Beside the lack of volunteers, the issue occurred with some other factors as well, such as the issue of trust of service users which was seen as a major obstacle to the implementation of the project itself. The fact that there are only six volunteers in the $60+$ project is in favour of the fact that volunteering and social activism have not unfortunately gained a huge momentum. Generally, experience shows that only a small proportion of older persons is visited by volunteers and that there is only a small number of those paying some third person to take care of them (Kepeš 2012). Reason for this is primarily due to small pensions and poverty, which directly results in the inability to pay for such services. The Bosnian society for the last two decades has not developed an adequate system of services for sick older people who are depending on the help of others. The attempt to replace such services with certain non-sufficient amounts of money has proved to be inadequate solution.

In our research, we found that a smaller percentage of older individuals (4.9 \%) volunteered in NGOs and $39.8 \%$ of them said that they were informally helping others. As noted by Kepeš (2012), it is encouraging that $68 \%$ of older people actually express a desire to be active members of the community, although the society did not create any opportunities for them. The majority would like to pass on their knowledge $(70.7 \%)$ but they are not given the opportunity to do so. Likewise, it is important to point out that Healthy

6 Participating, encouraging or advocacy of any activity with the purpose of improving the quality of life in the local community. 
Aging Centres largely operate on principles of peer solidarity. Namely, most of the courses and programs are run by the older persons, who are at the same time the users and the service providers. This is not only an important mechanism of utilizing their knowledge and skills, but also of raising their confidence through a feeling of usefulness. Lack of motivation for more active participation in the community is often associated with skepticism that their knowledge and competences are no longer useful and that younger people are not interested in such knowledge any more. One of the main reasons is the lack of knowledge in computer technology, which makes all the other knowledge seem worthless. Finally, the knowledge and skills they possess are directly correlating with education level, work and life experience.

\section{Public transportation, mobility and outdoor spaces}

Everyday mobility of the vast majority of old-age persons often entirely depends on the public transport services, as it is the only way to reach desired destinations. Numerous infrastructural deficiencies existing in the City of Sarajevo do not exclusively affect senior citizens, but also a wider spectrum of population. Public transport is certainly one of them. The state of public city transportation gives a somber impression: obsolete vehicles of questionable technical roadworthiness, unreliability, poor coordination of lines, inadequate coverage of public transport services of all zones, lack of information on timetables, low frequencies to outer areas, uncomfortable travelling, overcrowded vehicles, often inaccessible both to fragile older people and persons with disabilities, insecurity of passengers, frequent deviations from timetables, etc.

The summarized criterion checklist to achieve satisfactory progress, and ultimately have public transport tailored to the citizens in the third age, includes the following items:

- Reliability and frequency of lines;

- Travel destinations (well-connected transport routes, all areas serviced at optimal level, including suburbs and neighboring towns...);

- Age-friendly vehicles (physical access to means of transport with low-floor, cleanliness in vehicles, clearly visible signage indicating number of vehicle and the name of the destination, displays within the vehicle and sound information announcing next stops along the transport route, etc.)

- Transport stops are well-distributed across city areas, easily accessible, provided with seating and with shelter) (WHO 2007).

Public transport is desperate. Depending on the city area, stops might be more than a kilometer away from one's home. Some lines are rare, vehicles overcrowded with passengers, so riding is uncomfortable and very often tedious. (Female 65+, residing in Novo Sarajevo)

Two thirds of respondents use public transport on a daily basis, while less than a fifth uses it a few times in a month. Opinions differ as to whether the means of public transport are partially or not at all appropriate for older persons (49\% vs. $45 \%$ respectively). Nearly three-quarters of respondents negatively rated the public transport service due to its unreliability or general inadequacy. Despite the differences in frequencies and experience in using public transport, it is evident that most respondents are not satisfied with this component of key life domains. 
In cities aspiring to become a place of comfortable living for older adults, the outdoor environment deserves special attention, as it represents the basic prerequisite for their social participation (Phillipson 2011). The terrain configuration of Sarajevo is extremely hilly, with slopes being its dominant feature. Non-functional construction and poor planning have resulted in the network of neighborhoods with steep and narrow streets without defined curbs and without sidewalks in many parts. During the winter months, especially after heavy snowfalls, the movement in many, primarily downhill parts of the city is very risky.

Certain types of issues are attached to some neighborhoods. The greatest number of hardships faced by aged persons in their daily lives regarding outdoor environment and mobility are to be found in illegally built settlements without adequate infrastructure as well as in big apartment blocks. It is of crucial importance to enable the unhindered and safe movement of older adults, otherwise, a significant percentage of them may experience social isolation and loneliness, which represent a major health risk for this population (Angel and Settersten 2011; Menec 2016). Almost three-quarters of those surveyed (74 \%) indicated that parked vehicles on the sidewalks make it difficult for pedestrians to move. Damaged or uneven stairways are recognized as an obstacle for movement by more than one third of respondents, while one quarter complained about the lack of street lights.

Older people greatly appreciate green spaces in the city, and notice its deficiency, primarily associated with building expansion that has been blooming over the last ten years. Like in other post-socialist cities, neoliberal urban practices are visible through gentrification and erection of high-rise buildings "occupying" undeveloped open spaces (Jadžić 2011). During the reconstruction and revitalization of urban spaces many significant factors (ventilation corridors, wind rose etc.) are disregarded, causing ecological disruption of the city ${ }^{7}$. Apart from the size, the even distribution of green areas across the city is equally important to most citizens, which is not the case in Sarajevo. All respondents agree with the claim that more green areas are needed in their hometown, as expected.

I would like more green areas and parks in Sarajevo. In many parts of the neighborhood there is no even a bench beside the promenade, so tired people cannot take a break during the stroll. (Female 65+, residing in Novi Grad)

Existing parks, except perhaps those located in the very city centre, require better arrangement, regular maintenance, and additional equipment to make the ambience more comfortable and thus pleasant for stay. In doing so, the combination of various functions of abovementioned spaces such as rest, recreation and social interaction would be achieved (Artmann et al. 2017).

The issue of air pollution is particularly evident in the winter period when a large number of households and other entities, instead of gas, use environmentally unacceptable fuel for space heating. Consequently, Sarajevo is ranked among the most polluted cities in Europe (Huterer 2016). Usually intensified from November, in addition to causing an extraordinary situation due to reduced visibility, the polllution seriously endangers human health. 


\section{Concluding remarks}

Bosnia and Herzegovina, as a post-conflict and transitional society, is dealing with numerous problems such as poverty, unemployment, and general social insecurity, with vulnerable categories who are continuously marginalized. Both forced and voluntary migrations, during and after the war, resulted in a dramatic change of demographic structure. Therefore, population ageing has been generating not only by low birth rates but also by external migration. Many research findings have shown that the quality of life among older people is mostly worse compared with the rest of the population due to their health status, insufficient financial resources, loneliness and social exclusion (e.g. Scharf et al. 2000; Gabriel and Bowling 2004; Sováriová Soósová 2016).

Low living standard of the majorty of retirees, as well as life in poverty are the main limiting factors for healthy life of this age group. Furthermore, active aging is determined by one's health condition, level of education, social and cultural background. In spite of negative macro indicators, older persons covered in the survey are quite content with their life, which is mostly related to the strong bonds with their friends and family. It should be borne in mind that the research has been limited to the users of centres for healthy ageing only, so it does not provide an overall picture of senior citizes in Sarajevo. High percentage of them are exposed to the risk of social exclusion, likely greater than their counterparts who participated in the survey.

Apart from one's individual circumstances, opportunities for active ageing depend to a large extent on investments in societal framework (Tesch-Roemer 2012). Weak welfare regimes, as it is the case in Bosnia and Herzegovina, are impotent to enhance well-being of older people. Physical, economic and social environment are aggravating factors, and as such are not encouraging healthy and active aging in Sarajevo. The response of the few local communities in narrow city centres to the growing needs of older people in the City of Sarajevo represents a positive example of social sensitivity which addresses the needs of this population. This serves as an opportunity for bringing the concept of healthy and active aging closer to all citizens, and not for restricting it only for a minority with better socio-economic chances.

Despite the numerous advantages that the city itself offers, there are many segments that need to be improved, especially when it comes to infrastructure, the service sector, and generally speaking, better living conditions. The majority of respondents are not content with public transport services, urban green space availability and outdoor spaces overall, especially when residing outside the central zone. Although the Global Network of Age-Friendly Cities is growing, there are still no promotional activities aimed at affirmation of this concept in Bosnia and Herzegovina. However, certain challenges and weaknesses of implementing the Age-Friendly City (AFC) model in other countries have been identified by researchers: cost-neutral approach, i.e. austerity policies (Walsh and Harvey 2012, as cited in Buffel and Phillipson 2016), and its incompatibility with neo-liberal policies (Buffel and Phillipson 2016).

Nevertheless, good practices and urban policy responces of other cities striving to optimize conditions for active ageing (e.g. Barcelona, Manchester, Lisbon and many others) could serve as the benchmark for stakeholders in Sarajevo. 


\section{References}

ANGEL, Jacqueline L. and Richard A. SETTERSTEN, Jr. 2011. "Sociology in the Decades Ahead." Pp. 661-672 in Handbook of Sociology of Aging, edited by Richard A. SETTERSTEN, Jr. and Jacqueline L. ANGEL. New York: Springer.

ARTMANN, Martina, Xianwen CHEN, Cristian I. IOJA, Angela HOF, Diana A. ONOSE, Lidia PONIZY, Alma LAMOVŠEK ZAVODNIK and Jürgen BREUSTE. 2017. "The Role of Urban Green Spaces in Care Facilities for Elderly People across European Cities." Urban Forestry \& Urban Greening 27: 203-213.

BUFFEL, Tine and Chris PHILLIPSON. 2016. "Can Global Cities Be 'Age Friendly Cities'? Urban Development and Ageing Populations." Cities 55: 94-100.

CARITAS BISKUPSKE KONFERENCIJE BOSNE I HERCEGOVINE. 2012. Izvješce o siromaštvu 2012. Sarajevo: Caritas Biskupske konferencije Bosne i Hercegovine. Retrieved 25 September, 2017 (http://www.caritas.ba/dok/1417627543.pdf).

CARITAS BISKUPSKE KONFERENCIJE BOSNE I HERCEGOVINE. 2010. Pričali smo sa siromasima-Siromaštvo i socijalna isključenost koje uočava Katolička crkva u Bosni i Hercegovini. Sarajevo: Caritas Biskupske konferencije Bosne i Hercegovine, Retrieved 25 September, 2017 (http://www.caritas.ba/dok/1455282604.pdf.)

GABRIEL, Zahava and Ann BOWLING. 2004 "Quality of Life from the Perspectives of Older People." Ageing and Society 24(5): 675-691.

HUTERER, Dražen. 2016. "Neslavna titula: Sarajevo među najzagađenijim gradovima Evrope" VOA News, 23, December. Retrieved September 25, 2017 (https://ba.voanews.com/a/ zagadjenje-zraka-satajevo-magla/3648013.html)

INSTITUTE FOR STATISTICS OF THE FEDERATION OF BOSNIA AND HERZEGOVINA. 2017. Census Results 2013. Sarajevo: Institute for Statistics of the Federation of Bosnia and Herzegovina. Retrieved September 25, 2017 (http://fzs.ba)

JADŽIĆ, Miloš. 2011. "Prostor, urbanizam, politika u postsocijalistčkom gradu." Pp. 116-131 in Izgubljeno u tranziciji: Kritička analiza procesa društvene transformacije, edited by Ana VESELINOVIĆ, Petar ATANCKOVIĆ and Željko KLARIĆ. Beograd: Rosa Luxemburg Stiftung.

KEPEŠ, Nusreta. 2012. Identifikacija i etiologija trenutnog stanja i položaja osoba treće životne dobi u BiH- istraživačka studija, Gračanica: Osmijeh.

MENEC, Verena. 2016. "Loneliness and Social Isolation are Important Health Risks in the Elderly." McMaster Optimal Aging Portal, April 8. Retrieved September 25, 2017 (https:/www.mcmasteroptimalaging.org/ blog/detail/professionals-blog/2016/04/08/loneliness-and-social-isolation-are-important-health-risksin-the-elderly).

MINISTARSTVO FINANSIJA I TREZORA BIH I UNCT. 2013. Napredak $u$ realizaciji Milenijskih razvojnih ciljeva u Bosni i Hercegovini. Sarajevo: Ministarstvo finansija i trezora BiH i UNCT.

NOVAK, Mark. 1993. Aging and Society: A Canadian Perspective. Scarborough, ON: Nelson Canada.

PHILlIPSON, Chris. 2007. "Understanding the Baby Boom Generation: Comparative Perspectives." International Journal of Ageing and Later Life 2(2): 7-11.

PHILlIPSON, Chris. 2011. "Developing Age-Friendly Communities: New Approaches to Growing Old in Urban Communities.” Pp. 279-296 in Handbook of Sociology of Aging, edited by Richard A.SETTERSTEN, Jr. and Jacqueline L. ANGEL. New York: Springer.

RAZVOJNI PROGRAM UJEDINJENIH NACIJA(UNDP). 2013. Ruralni razvoj u Bosni i Hercegovini: mit ili stvarnost. Sarajevo: UNDP. Retrieved September 25, 2017 (http://www.ba.undp.org/content/ dam/bosnia_and_herzegovina/docs/Research\&Publications/HDR/2013/NHDR2013/BiH_NHDR Brochure.pdf). 
SCHARF, Thomas, Chris PHILliPSON, Paul KINGSTON and Alison E. SMITH. 2000. "Social Exclusion and Older People: Towards a Conceptual Framework." Working Paper 6. Centre for Social Gerontology, Keele University: Keele Press.

SOVÁRIOVÁ SOÓSOVÁ, Mária. 2016. "Determinants of Quality of Life in the Elderly". Central European Journal of Nursing and Midwifery 7(3): 484-493.

STRATEGIJA ZA UNAPREĐENJE POLOŽAJA STARIJIH OSOBA U FEDERACIJI BOSNE I HERCEGOVINE 2018. - 2027. 2017. Retrieved September, 252017 (http://www.fmrsp.gov.ba).

TESCH-RÖMER, Clemens. 2012. Active Ageing and Quality of Life in Old Age. New York: United Nations.

UNITED NATIONS, DEPARTMENT OF ECONOMIC AND SOCIAL AFFAIRS, POPULATION DIVISION. 2015. World Population Prospects: The 2015 Revision, Key Findings and Advance Tables. Retrieved September 19, 2017 (https://esa.un.org/unpd/wpp/publications/files/key_ findings_wpp_2015.pdf).

VULETIĆ, Gorka and Marina STAPIĆ. 2013. "Kvaliteta života i doživljaj usamljenosti kod osoba starije životne dobi.” Klinička psihologija 6(1-2): 45-61.

WALSH, Kieran, Thomas SCHARF and Norah KEATING. 2016. "Social Exclusion of Older Persons: A Scoping Review and Conceptual Framework." European Journal of Ageing 14(1): 81-98.

WORLD HEALTH ORGANIZATION. 2007. Global Age-friendly Cities: A Guide. Geneva: World Health Organization.

\section{Authors}

Mirza Emirhafizović is Assistant Professor at Department of Sociology, Faculty of Political Sciences, University of Sarajevo. Additionally, he has been Head of the Center for Migration Studies (CMS) within the Institute for Social Research of the Faculty since 2017. His research interests are primarily in the areas of social demography, migration studies, intergenerational family solidarity and urban sociology. He was involved in several research projects on fertility and migration. He has actively participated in five COST Actions (CA) since 2014, being the PhD Forum chair within CA ROSEnet and Working Group leader of CA Transdisciplinary solutions to cross sectoral disadvantage in youth.

Contact: mirza.emirhafizovic@fpn.unsa.ba

Sanela Šadić is Associate Professor at Department of Social Work, Faculty of Political Sciences of University of Sarajevo. Her research interests are in human rights and ethics, family, intergenerational solidarity, solidarity and trust, migration. She is member of the International Association of Social Workers, active member of the Association of Social Workers of Sarajevo Canton and board member, member of the editorial board of the scientific journal Socijalne teme (Social Topics), author of the book Human rights and Social Work (2014), as well as author and co-author of few books and articles published in international and domestic journals, coordinator and team member of organizing committees of numerous international and domestic conferences.

Contact: sanela.sadic@fpn.unsa.ba 